IDEA - Studia nad strukturą i rozwojem pojęć filozoficznych

\title{
MICHAŁ KAMIŃSKI
}

(Kraków)

\section{POGLĄDY SENEKI NA TEMAT SAMOBÓJSTWA I ICH ZNACZENIE DLA WSPÓŁCZESNEJ DEBATY W ZAKRESIE DOPUSZCZALNOŚCI EUTANAZJI I SAMOBÓJSTWA WSPOMAGANEGO}

\author{
Nie chciał żyć, kto nie chce umrzeć. \\ Życie bowiem zostało dane pod warunkiem śmierci. \\ Ku niej idziemy. Dlatego głupotą jest lękać się jej, \\ ponieważ boimy się tego co niepewne, \\ na to co pewne czekamy.
}

Seneka

\section{Wstęp}

Spór wokół problemu śmierci i zagadnień jej towarzyszących sięga już czasów starożytnych. Nie oznacza to jednak, że starożytność wyczerpuje ten temat zarówno w zakresie rozważań filozoficznych, jak i stosunku prawa do samobójstwa. Wręcz przeciwnie - problem decydowania o własnej śmierci był przedmiotem rozważań na przestrzeni kolejnych wieków tak na gruncie filozofii czy teologii, jak i etyki, a wreszcie prawa. Również współcześnie samobójstwo jest tematem otwartym, zaś spory wokół jego dopuszczalności nie milkną. W ostatnich latach samobójstwo stało się zagadnieniem szczególnie aktualnym dla instytucji stanowiących prawo w całej Europie. Dyskusje na temat prawa nie tylko do życia, ale również do śmierci, odżyły za sprawą legalizacji samobójstwa przez rząd Albanii, który to ustawa o prawach osób nieuleczalnie chorych w 1999 roku, jako pierwszy kraj europejski, zalegalizował eutanazję:

Euthanasia means accelerated death of the person who suffers from an incurable disease, triggering fatal or serious physical abnormality, which aggravates the mental, emotional or physical state of the patient (terminal illness), and that can be caused 
in different ways and from different subjects, under the clear and continuous desire of the patient, with the only interest of giving an end to his sufferings ${ }^{1}$.

Środkami eutanazji jest przyspieszenie śmierci osoby, która cierpi z powodu nieuleczalnej choroby, powodującej śmierć lub poważne nieprawidłowości fizyczne pogłębiając negatywny stan psychiczny, emocjonalny i fizyczny pacjenta. Może być przeprowadzona na różne sposoby i z różnych powodów, jednak na wyraźną i nieprzerwaną prośbę zainteresowanego dając kres jego cierpieniom.

Usankcjonowanie eutanazji przez Albanię spowodowało podjęcie tematu prawa do śmierci przez prawodastwo krajów europejskich, zaś na przestrzeni ostatnich 15 lat tą samą drogą poszła również Belgia, Luksemburg i Holandia oraz, z pewnymi wyjątkami, Szwajcaria i Niemcy. Kraje te to jedynie wierzchołek góry lodowej, gdyż obecnie nad legalizacją eutanazji pracuje również Litwa. Europa nie jest też jedynym kontynentem, na którym dopuszcza się śmierć na żądanie i z pewnością listę tę uzupełnić może Japonia czy niektóre stany USA.

Problem eutanazji jest jednak złożony i możemy rozważać go przynajmniej w dwóch aspektach. Pierwszym jest prawo do śmierci, gdzie zainteresowany sam może decydować o czasie i sposobie odejścia. W tym kontekście rozważać możemy czysto teoretycznie na temat etycznych czy moralnych podstaw oraz analizować koncepcje filozoficzne lub religijne, które dają szereg argumentów na to, czy prawo do samounicestwienia jest tym, co leży w gestii człowieka. Drugim aspektem, o wiele bardziej złożnym, jest praktyczne przeprowadzenie eutanazji. Pomoc w popełnieniu samobójstwa (assisted suicide) to nie tylko problem etycznych czy moralnych przekonań motywowanych przez posiadany system wartości, ale także problem prawny i odpowiedzialności karnej za sprawstwo i współsprawstwo (art. $18 \mathrm{kk}$ ), za przygotowanie (art. $16 \mathrm{kk}$ ) i pomocnictwo (art. $19 \mathrm{kk}$ ).

Jak zatem widzimy eutanazja obecnie to nie tylko problem przekonań, ale przede wszystkim odpowiedzialności za pomoc w jej przeprowadzeniu. Problem odpowiedzialności za współudział nie pojawia się jednak wyłącznie w dzisiejszych czasach, ale ma swój rodowód już w starożytności. Choć z aktu samobójstwa często czyniono widowisko, to jednak w większości przypadków prawnie ten czyn był zabroniony, toteż i często pozorowany, jako śmierć niezamierzona. Samobójca „nie pozbawił się jednak życia w sposób nagły; kazał sobie przeciąć żyły, lecz według upodobania je podwiązywał, potem znów otwierał i przemawiał do przyjaciół, nie mówiąc nic poważnego ani takiego, czym by mógł sobie sławę stateczności pozyskać. [...] Zasiadł do uczty, oddał się drzemce, aby śmierć, aczkolwiek wymuszona, do przypadkowej była podobna" 2 .

1 http://www.diritto.it/docs/32741-euthanasia-last-life-right-and-albanian-legislation?page=1.

2 Tacyt, Dziela, przeł. S. Hammer, Warszawa 2004, s. 381. 
Nie sposób jednak zaprzeczyć, że jednocześnie już u Starożytnych dopuszczane było prawo do decydowania o własnej śmierci. Nie była to jednak decyzja podejmowana spontanicznie, ale poprzedzona szeregiem kryteriów, jakie należało spełnić, aby móc targnąć się na własne życie.

Niniejszy artykuł ma przedstawić, jak do zagadnienia samobójstwa podchodzili stoicy. Jakie argumenty z poglądów Zenona z Kition, Seneki czy Marka Aureliusza na korzyść śmierci eutanatycznej możemy przytoczyć również w dzisiejszych debatach na temat prawa do decydowania o własnej śmierci.

Niniejszy artykuł jest próbą znalezienia odpowiedzi na pytanie, czy samobójstwo powinno być prawnie dopuszczane. A jeśli tak, to w jakich przypadkach. Ponieważ jednymi z pierwszych myślicieli, którzy wprowadzili dopuszczalność eutanazji (bez względu na stan zdrowia) byli stoicy, to właśnie na ich poglądach będę starał się ująć te sytuacje, w których nad samobójstwem warto się bliżej zastanowić. Ponieważ jednak każdy nurt czy szkoła opiera się na myśli swoich przedstawicieli, to poza ogólnym rysem stoickiego pojmowania świata i problemu śmierci, przedstawię poglądy w tym zakresie trzech najbardziej znaczaccych stoików: Zenona z Kition, Seneki oraz Marka Aureliusza. Wybór ten nie jest przypadkowy, gdyż każdy z nich oprócz wkładu indywidualnego w problem tanatyzmu, reprezentuje kolejno następująco po sobie okresy szkoły stoickiej. Szczególne miejsce zajmować tutaj będzie Seneka, jako przedstawiciel dojrzałego okresu rozwoju stoicyzmu, dlatego w jego przypadku osobno przedstawionym jest problem śmierci i stosunku do niej oraz problem samobójstwa, jako rodzaju wywołania śmierci. Następnie przedstawię poglądy Marka Aureliusza, jako przedstawiciela schyłkowego etapu szkoły stoickiej, jednocześnie wykazując, jak bardzo te poglądy na śmierć i samobójstwo pozostają aktualne również dzisiaj, posiadając ponadczasowy wymiar problemu.

Celem niniejszego artykułu obok przybliżenia poglądów stoików, głównie w osobie Seneki i Aureliusza, jest również wykazanie, jak bardzo zakaz stosowania eutanazji wkracza w sferę wolności człowieka.

\section{Stoicka gotowość na śmieré}

Właściwa argumentacja, a co za tym idzie również rozumienie stoickich poglądów, ma swoje źródło w panteistycznym widzeniu świata, które było podstawą do ukształtowania materialistycznej koncepcji przyrody, a co za tym idzie również materialnego istnienia duszy i człowieka. Stoicki świat posiada rozumny i celowościowy charakter, zaś istotami, które ten cel nadają i sprawiają, że w ogóle możliwe są jakiekolwiek przemiany, są między innymi ludzie. W ten sposób ma- 
teria nabiera jednocześnie cech duchowych, zaś świat duchowy istnieje nie poza światem materialnym, ale w nim. Materializm ten różnił się jednak od atomizmu tym, że stoicki świat rozumiany był organistycznie, jako zespolony układ części, które stanowią całość i w tej całości funkcjonują jako jeden organizm.

To rozwiązało problem dualizmu duszy i ciała czyniąc z duszy ludzkiej składnik wszechświata, a nie indywidualną przypadłość. „Dusze ludzkie są wprawdzie cielesne, ale są ciałami pneumatycznymi, których ruch toniczny ma wysokie napięcie. Nie są wieczne, ale są trwalsze od ciał [...] dusze mędrców trwają aż po pożar świata. Stąd zadanie człowieka [...] żyć zgodnie z wszechświatem i być wiernym prawu, które całą naturą rządzi" 3. Pogląd taki czyni też istotę ludzką bytem o ściśle określonym istnieniu w czasie, bez perspektywy życia wiecznego w formie duchowej. Wedle stoików istoty ludzkie nie biorą udziału w indywidualnej wędrówce duszy po zaświatach, ale trwaja jedynie tutaj, zaś sposób ich życia pozwala wypełnić porządek świata. Jednocześnie sprowadzenie człowieka wyłącznie do materii wyznacza też jemu nową rolę, jako elementu wielkiej jedni. Do niej to człowiek wraca po śmierci jako kosmicznej całości i w niej rozpływa się na wieczność. Życie polega więc na zgodności, na zharmonizowaniu się z naturą, której człowiek nie jest władcą, ale jednie częścią.

Wprawdzie dusze ludzkie nie są już wiecznymi bytami, jak to było u poprzedników, ale potrafią trwać jeszcze po śmierci, zaś czas ich trwania zależy od napięć, jakie dusza zdobywa podczas życia. Sens życia i śmierci to właśnie powrót do wszechświata jako całości. Człowiek nabiera nowego znaczenia, nie jest istotą indywidualną, ale częścią składową wielkiego organizmu i tym samym nie może pozostawać w opozycji do tego, co z naturą zgodne; a skoro śmierć jest naturalna, to żaden mądry człowiek nie powinien się lękać śmierci i wzbraniać przed jej nadejściem.

Wyjątek w rozproszeniu w materii stanowią osoby oświecone, zwane mędrcami lub filozofami, gdyż reprezentują grupę o najwyższym poziomie świadomości. Są to osoby, które pozostają gotowe, aby w każdym dowolnym momencie pozostawić to życie i wyjść ku śmierci. Postawa taka wcale nie jest łatwa, gdyż to właśnie w obliczu śmierci człowiek najbardziej pragnie żyć. Przecież „owoce są najsmaczniejsze, kiedy się kończą. Dzieciństwo najpiękniejsze jest, kiedy się z niego wyrasta. Pijakom największą przyjemność sprawia ostatni kielich wina, ten, który ich pogrąża, który wieńczy pijaństwo. Wszelka rozkosz odsuwa na sam koniec to, co ma w sobie najmilszego. Najprzyjemniejszy jest wiek już podeszły, ale jeszcze nie podupadły. A nawet i ów, uważam, stojący na samej krawędzi życia, ma swoje przyjemności. Albo już samo to zastępuje przyjemności,

3 W. Tatarkiewicz, Historia filozofi, t. 1, Warszawa 1968, s. 145. 
że wcale się nie odczuwa ich braku" 4. Do śmierci należy się więc długo przygotowywać poznając mechanizmy wszechświata, a wówczas poznając samych siebie, bez sprzeciwu dla prawa natury, będziemy pierwsi, aby pójść na powrót tam, skąd przyszliśmy.

Teoria wiecznego powrotu, jaka pojawia się w poglądach stoików, rzuca zupełnie inne światło na problem śmierci. Stoicyzm w pewnym względzie zawiera podobną konstrukcję, jak ma to miejsce w koncepcjach wcześniejszych, z tą różnicą, że np. u Arystotelesa człowiek oprócz tego, że jest istotą społeczną, jest też istotą państwową. Ma służyć dobru państwa i przez państwo jest zdominowany. Nie bóg, ale obowiązki państwowe mają hamować człowieka przed samobójstwem. U stoików człowiek również jest istotą społeczną, ale w państwie jest jedynie osadzony, co oznacza większą swobodę decydowania o swoim losie. Owszem, obywatel jest zaangażowany w losy ojczyzny, ale ma też prawo decydować o swoim odejściu, kiedy tym obowiązkom nie może sprostać.

Stoikom droge do autodestrukcji dodatkowo ułatwia wolnościowy i niezależnościowy stosunek człowieka do sił wyższych. Człowiek bowiem nie żyje z misją zbawienia swojej duszy, nie jest on kierowany przez żadne bóstwo, które w swoim zamyśle posiada względem człowieka jakiś wyjątkowy plan i tym samym wyłączność do decydowania o momencie jego śmierci. Życie zostaje wypełnione w określonym momencie, po którym nie ma powodu, aby zawieszonym w przestrzeni kurczowo trzymać się życia. Nie oznacza to jednak, że samobójstwo było aprobowane w dowolnym momencie życia.

Dla założyciela szkoły stoickiej Zenona z Kition akt ten był dopuszczalny tylko w wybranych przypadkach. Do podstawowych należało zniedołężnienie powodowane wiekiem lub chorobą, co stanowi punkt oparcia dla współczesnych debat na temat legalizacji eutanazji, jako procesu umożliwiajaccego zachowanie prawa do godnego i świadomego umierania. Inne argumenty, jakie podaje szkoła stoicka, traciły na wartości wraz z ewolucją światopoglądową i świadomościową społeczeństwa europejskiego. Np. utrata czci czy honoru, jako powód do odebrania sobie życia, stanowiła argument jeszcze do XIX wieku, zaś w Japonii jest nim do dziś. Najczęściej jednak pojawiającym się powodem targnięcia na własne życie jest dla stoików ananke czyli przymus lub pewna konieczność, po którą sięgnął np. Seneka.

Przyzwolenie na śmierć rozszerza się nie tylko o zagadnienia niedołęstwa czy pasywności organów, ale również o niechęć do dalszego życia. Samobójstwo u stoików w schyłkowym okresie istnienia szkoły osiąga taką skrajność, że ich poglądy etyczne w tym zakresie często określa się już tylko mianem eskapizmu, gdyż samobójstwo stało się sposobem na ucieczkę od niedogodności, a nie jak pierwotnie

4 Seneka, Myśli, przeł. S. Stabryła, Gdańsk 2000, s. 157. 
chciano skróceniem cierpień w chorobie. Bez względu na to, czy powodem będzie niechęć czy lęk, samobójstwo pozostaje kwestią wolnego wyboru i tym samym jest ono wpisane w ramy pojęcia wolności.

Wolność wyrażona w ten specyficzny sposób stanowi przywilej, z którego można skorzystać, co oczywiście nie oznacza konieczności czy przymusu sięgania po tę możliwość. Wprawdzie istnieją zagrożenia nadużyć, ale tak naprawdę to, co stanowi problem, to nie sama legalizacja eutanazji, co sposób jej przeprowadzenia. O możliwość dobrowolnego odejścia w czasach rozwoju starożytnej filozofii szczególnie zabiegali stoicy czyniąc z samobójstwa niekwestionowany wyraz wolności i manifestacji wolnej woli.

Stoicyzm w filozofii nie świadczy więc o obojętności wobec świata, ale jest osiągnięciem najwyższego stanu świadomości, który człowiek może osiągnąć. Owa niewrażliwość na ból i cierpienie, a przy tym zgoda na wszelkie nieprzyjemności, świadczyć ma o osiągnięciu cnoty, a nie obojętności. Człowiek wyzbyty pragnień i emocji osiąga prawdziwą wolność. Mędrca nie ograniczają te same niskie pobudki i namiętności, z jakimi zmaga się przeciętna osoba. „Jest [on] wyzwolony spod praw rodzaju ludzkiego, jemu jednemu są podległe wszystkie stulecia jak gdyby jakiemuś bogu" ${ }^{5}$. Mędrzec może tego dokonać tylko dlatego, że wyzbywa się wszelkich afektów, jako czynników sztucznych i szkodliwych. Apatia jest więc drogą do doskonałości i przygotowaniem na śmierć, gdyż dzięki niej człowiek jest pogodzony, czysty i wolny, a zatem gotowy, aby dokonać swego żywota zamykając cykl, w jakim tkwi. Jak łatwo można spostrzec, życie polega na przygotowywaniu i wyczekiwaniu śmierci.

Apatia w stoicyzmie nabiera pozytywnego wydźwięku, jest ona beznamiętnością, którą wypełniony powinien być człowiek. Umysł pozbawiony namiętności pozostaje prawdziwie wolny i zdolny do działania dla większej idei, a nie jedynie osobistych pobudek. Najgorszą trucizną, jaka nas trawi, jest smutek, gdyż najczęściej rodzi on współczucie, a to znów zawraca mędrca z drogi rozumu na drogę emocji. Te zaś świadczą o niższym szczeblu rozwoju wewnętrznego, gdyż rozum winien kierować się rozsądkiem, a nie emocjami ${ }^{6}$.

Filozof osiąga więc pełnię swojego życia tutaj, a nie w innym wymiarze bytu. Życie na ziemi jest jedno, dane raz i służy do osiągnięcia cnoty jako celu. Pogląd ten naznacza wyraźną rozbieżność pomiędzy stoikami a wcześniejszą szkoła grecką, gdzie dusza ludzka dopiero po śmierci mogła się realizować. Śmierć ciała u poprzedników otwiera kolejny etap życia w nowej formie, u stoików

\footnotetext{
5 Seneka, Dialogi, tłum. S. Stabryła, Warszawa 1998, s. 148.

6 Na dominacji rozsądku nad emocjami opiera się stoicka etyka, w której liczą się intencje a nie afekty.
} 
jest ona dopełnieniem życia. Problem w tym, że najczęściej wola życia u człowieka jest tak silna, że śmierci stają naprzeciw emocje, które sprzeciwiają się rozumowi. Ten, kto nie osiągnął doskonałego stanu poznania natury, kto staje naprzeciw życiu, będzie unikać śmierci szukając sposobności, aby przeżyć kolejny dzień lub rozpalając nadzieję na drugie życie. „Zasługuje na refleksję zasadniczo dwojaka reakcja myśli filozoficznej na fatum śmierci ludzkiej. Jeden nurt skłania się ku uporczywej obronie naturalnego prawa do życia; z melancholią, obawą, a nawet strachem rozważa realność śmierci osobniczej. [...] Drugi nurt [...] przyjmuje ją jako zjawisko konieczne, nieuchronne, wpisane w odwieczne prawidłowości kosmosu. Jego zwolennicy zachęcają do przyjmowania śmierci ze spokojem, zrozumieniem, bez obaw z godnością, jakiej należy oczekiwać od istoty rozumnej" 7. I właśnie ten drugi pogląd wyrażać będzie stanowisko Seneki do śmierci.

\section{2. Śmierć w poglądach Seneki}

Na poglądy dotyczące śmierci i jej rodzaju, jakim jest samobójstwo, składają się u Seneki dwa czynniki. Pierwszym jest stoicki fundament etyczny, drugim - życie własne u boku cesarza Nerona, którego wychowaniem, a potem pełniąc rolę doradcy, zajmował się Burrus i właśnie Seneka. Rządy, jakie sprawował Neron, zmusiły Senekę do opuszczenia pałacu, zaś ostatecznie został przez Nerona oskarżony o udział w spisku. Właśnie ten czynnik nie pozostaje bez znaczenia dla zapatrywań na śmierć przez filozofa. I nie chodzi tutaj tylko o pozanaturalne postrzeganie śmierci, ale traktowanie jej jako ucieczki i najwyższego wymiaru wyzwolenia od ludzkiej niesprawiedliwości i tyrani.

Śmierć nabiera zatem nowego wymiaru. Nie jest ona cierpieniem i udręką, nie napawa lękiem, ale jest czymś długo oczekiwanym, co stanowi ukoronowanie życia. „W samej śmierci nie ma nic nieprzyjemnego. To, co miałoby doznać nieprzyjemności, musi bowiem istnieć. Jeśli ogarnia cię żądza dłuższego życia, pomyśl, że nic, co znika z oczu wchłonięte przez Naturę, z której się wyłoniło i z której wkrótce znów się wyłoni, nie ulega całkowitemu zniszczeniu: osiąga tylko swój kres, lecz nie przepada, a śmierć, która przeraża nas i od której się wymawiamy, przerywa życie, ale nie wydziera. Nadejdzie znowu dzień, który nas przywróci na światło, a przed którym wielu by się wzbraniało, gdyby ich miał znowu sprowadzić bez zatarcia dawnej pamięci" ${ }^{8}$. Nie oznacza to jednak, że każda śmierć jest dobra,

\footnotetext{
7 Tokarczyk R., Prawa narodzin, życia i śmierci, Lublin 1995, s. 94.

8 Seneka, Myśli.., wyd. cyt., s. 165.
} 
gdyż do śmierci należy się przygotować mądrze na drodze cnoty. Śmierć wpisana w przyszłość życia staje się jego celem. Jest tym, czego uchwycić nie można, a co niewątpliwie istnieje.

W spektaklu śmierci uczestniczymy każdego dnia. Z każdym dniem jakaś część nas odchodzi i z wolna umieramy. Na przestrzeni lat możemy powiedzieć, że wielu śmierciom ulegliśmy, najpierw przechodząc z noworodków w dzieci, następnie stając się młodzieńcami, ludźmi dorosłymi, aż wreszcie starcami. Śmierć to proces płynnego i nieodczuwalnego przechodzenia jednego stanu w drugi, aż do czasu, kiedy wchodzimy w ostatni etap życia. „Umieramy co dzień. Co dzień bowiem tracimy jakąś cząstkę życia, a nawet wtedy, kiedy rośniemy, życie maleje. Najpierw mija niemowlęctwo, potem dzieciństwo, a wreszcie młodość. Każda miniona chwila aż po dzień wczorajszy jest już na zawsze stracona; nawet ten dzień, który właśnie przeżywamy, musimy dzielić ze śmiercią. Jak klepsydry nie opróżnia ostatnia kropla, lecz wszystka przedtem wysączona woda, tak i naszej śmierci nie powoduje dopiero ostatnia godzina, w której przestajemy istnieć, lecz ona ją tylko dopełnia: doszliśmy do niej, ale szliśmy długo" ${ }^{9}$. Niepojętym jest, że oto, kiedy czeka na nas to ostatnie przejście, wówczas pojawia się w nas lęk. Również niewytłumaczalnym jest spotykane wśród ludzi zaskoczenie niespodziewalności tego zjawiska. Śmierć jest cząstką jak ziarna w klepsydrze, a jej dokonanie to zbiór wszystkich ziaren, a nie tylko konsekwencja tego ostatniego.

Dlaczego zatem człowiek lęka się śmierci? Bo „oto największa część życia upływa nam na niewłaściwym działaniu, znaczna na bezczynności, a całe życie na czynieniu czego innego, niżby należało. Kogóż mi wskażesz, dla kogo czas przedstawiałby jakąś wartość, kto by cenił każdy dzień, kto by sobie zdawał sprawę, że codziennie umiera? Błąd nasz polega na tym, że śmierć dopiero przewidujemy: tymczasem ona w dużym stopniu już się dokonała. Każdą chwilę życia, która jest za nami, zagarnia śmierć" ${ }^{10}$. Sprzeciw wobec śmierci jest sprzeciwem wobec przeżytego życia, wobec niewłaściwie wykorzystanego czasu i zmarnowanych szans. Buntuje się ten, kto nie godzi się z życiem, kto nie godzi się z konsekwencjami jakie pojawiły się w momencie śmierci, a te przecież nie są wynikiem przejścia do nicości, ale skutkiem tego, że źle przeżyliśmy swoje życie. Nie ma zatem uzasadnienia wobec buntu przeciw śmierci. Życie to przecież pogodzenie się ze śmiercią, to oczekiwanie na śmierć i każdy, kto wybiera życie, wybiera teź śmierć „kto nie chce umierać, nie chciał też żyć" 11.

\footnotetext{
9 Seneka, Listy..., wyd. cyt., s. 161.

10 Tamże, s. 156.

11 Tamże, s. 138.
} 
Lęk przed śmiercią jest oczywiście czymś naturalnym. To emocje, które targają każdym, kto odczuwa jakiś brak i stara się ów brak uzupełnić życiem po śmierci czy to ideą nagrody czy kary, transformacji itd. Mędrzec jest pogodzony ze śmiercią, gdyż na tym ziemskim etapie osiągnął on wszystko czego pragnął, zaś tym maksymalnym wyznacznikiem, jaki można osiągnąć, jest cnota, stanowiąca wartość samą w sobie. Jest ona nagrodą, której nie trzeba już poszukiwać w zaświatach tworząc baśniowe krainy na wzór Platona czy Epikura. I nawet, jeśli cnocie towarzyszy szczęście, jako rodzaj namiętności, to wysuwa się ono na drugi plan. Jednak w porównaniu do Epikura czy innych filozofów, szczęście jest czymś pobocznym, co towarzyszy cnocie, a nie odwrotnie. Odwrócenie tej zasady charakteryzuje właśnie Senekę, dla którego cnota powinna być wolna od wszelkich namiętności, gdyż te biorą się nie z rozsądku, ale z błędów rozumu.

Dla stoików namiętności - emocje są największą zgubą zarówno dla umysłu, jak i dla ducha. Stanem doskonałym byłoby ich całkowite wyeliminowanie, wówczas rozum byłby wolny i mógł prawdziwie oceniać rzeczywistość. Również w przypadku śmierci, kiedy pojawia się rozpacz po utracie kogoś bliskiego, rozum dopuszcza do siebie żal i mami umysł. Człowiek w takim stanie nie może racjonalnie myśleć i podejmować decyzji, gdyż rozsądek jest przyćmiony przez emocje. Jest bowiem niedorzecznym rozpaczać nad czymś, nad czym nie panujemy i na co nie mamy żadnego wpływu. We współczesnych debatach na temat śmierci, zwłaszcza eutanatycznej, pojawia się stosunkowo często wyrażony w formie obaw, powyższy argument stoicki. Strach dotyczy wypaczenia natury ludzkiej, zobojętnienia w podejściu do cierpienia i śmierci drugiego człowieka i właśnie ta obojętność, mająca powodować przedmiotowe podejście do życia drugiego człowieka, jest przedmiotem dysputy na temat wartości ludzkiej i godności człowieka we współczesnych etykach i koncepcjach społecznych. Uważa się, że legalizacja eutanazji prowadzić będzie do sukcesywnego eliminowania jednostek chorych i nieprzydatnych społeczeństwu, jednak obawy przed takim zagrożeniem niewiele mają wspólnego ze stoicyzmem, który bardziej kładł akcent na problem możliwości decydowania o własnym losie, a nie decydowania za kogoś.

Unikanie emocji nie ma przecież prowadzić do oziębłości empatycznej, ale racjonalnego zmierzania się z zastanym problemem. Tym bardziej, jeśli o jego pojawieniu wiemy z wyprzedzeniem, a skoro śmierć jest nieuniknionym etapem, to rozpacz nad śmiercia jest jak rozpacz nad tym, że po lecie nadchodzi jesień. Toteż prawdziwie wolni i spokojni są ci, którzy nie myślą o tym, jakby o życie walczyć i pozostawać tutaj jak najdłużej. „Spokojnego życia nie może mieć nikt, kto zanadto myśli o przedłużeniu go, kto zalicza długie życie do wielkich dóbr. Nad tym codziennie rozmyślaj, abyś mógł spokojnie porzucić życie, którego wielu tak kurczowo się chwyta i czepia, jak owi, których uniósł rwący prąd rzeki, czepiają 
się cierni i ostrych skał. Wielu nieszczęśników miota się pomiędzy obawą śmierci a udrękami życia: i nie chcą żyć, i umrzeć nie potrafią. A więc uprzyjemniaj sobie życie, odpędzając wszelki niepokój o nie. Żadne dobro nie cieszy posiadacza, jeżeli on w duszy nie jest przygotowany na straty. Ale też żadna strata nie jest łatwiejsza do zniesienia niż taka, w której nie odczuwa się już braku rzeczy straconej" 12 . Na śmierć należy zatem być przygotowanym i żyć w oczekiwaniu, jakby w każdej chwili miała nadejść, a kiedy nadejdzie - z radością ją przyjąć. Wówczas pogodzeni i pełni spokoju możemy iść dalej. Możemy przejść ostatni etap śmierci, aby rozproszyć się w wiecznej nicości. Całkowity brak lęku przed śmiercią i obojętność wobec życia, ale też i obojętność wobec życia innych prowadzi do idealnego stanu apatii. Wszystkie bowiem problemy biorą się z emocji i właśnie nad nimi powinniśmy nauczyć się panować.

Lęk przed bezdusznym traktowaniem pacjenta i jego życia nie wyrasta zatem z poglądów filozoficznych, ale z indywidualnego stosunku do otoczenia. Stoicy starali się pogodzić ze śmiercią i traktować ją jako coś naturalnego i towarzyszącego nam każdego dnia, przez co trudno reagować emocjonalnie na coś, co dokonuje się w każdym momencie. Legalizacja eutanazji oraz brak odpowiedzialności karnej za pomoc w samobójstwie nie oznacza przecież, że zwiększy się ilość samobójstw wspomaganych. Stoicyzm ma nas zbliżyć do racjonalnego postrzegania śmierci, a nie jej masowej produkcji, czego obawiają się tak liczne grupy społeczne.

\section{O samobójstwie}

Poglądy etyczne Seneki zostały wybrane głównie z dwóch powodów: pierwszym jest ilość zachowanego materiału, który jest na tyle obszerny, aby nie budził wątpliwości. Drugim powodem jest okres, w którym przyszło mu żyć. Druga połowa pierwszego wieku to okres dojrzały szkoły stoickiej, a co za tym idzie, mamy do czynienia z uformowanymi już poglądami etycznymi. Samobójstwo jako jeden ze sposobów umierania nie jest obcy również Senece, zaś sposób pojmowania samobójstwa diametralnie różni go od wcześniejszych filozofów, np. Platona. Różnica ta jest fundamentalna, gdyż o ile Seneka upatrywał w samobójstwie sposobu na sprzeciw wobec życia i ucieczkę od życiowego trudu i ratunek dla duszy: „miarą wolności mędrca jest śmierć, która zawsze pozwala uniknąć groźby zniewolenia duszy" ${ }^{13}$, o tyle Platon uważał, że człowiek w żadnym wypadku nie powinien

12 Tamże, s. 154.

13 Karłowicz D., Problem samobójstwa. Refleksje nad ocena moralna samobójstwa u starożytnych filozofów, „Znak”, 12, 1997, s. 100. 
sam decydować o swojej śmierci: „toż nauka tajemna mówi o tej sprawie, że my, ludzie, jesteśmy niejako w więzieniu i nie wolno z niego siebie samego wyzwalać ani uciekać" 14 15. Jak zatem zauważamy, Platon godzi się na walkę, Seneka na ucieczkę. To znów stało się podstawą do tego, aby śmierć samobójczą uznać za godny sposób ucieczki i zachowania wolności duszy przed złym władcą i jego tyranią. „Śmierć albo niszczy nas, albo oswobadza. Wyzwolonym, po zdjęciu ciężaru, pozostaje to co lepsze, zniszczonym nie pozostaje nic. I dobro wtedy, i zło jednako ginie na zawsze" 16 .

Samobójstwo staje się sposobem na życie. Seneka staje również w opozycji do poglądów epikurejskich, gdyż ci rozumem panowali nad emocjami, aby stawić czoło śmierci. Seneka zaś dąży do panowania rozumowego nad emocjami, aby śmierci wyjść naprzeciw. „Filozof dąży do takiego stanu ducha, w którym człowiek dzięki sile swojego rozumu, dzięki rozmyślaniom, dzięki głębokiemu przekonaniu, że śmierć nie jest złem samym w sobie, do tego stopnia osłabi w sobie instynktowne przywiązanie do życia, że z całym spokojem umysłu będzie mógł decydować: żyć czy też umierać" ${ }^{17}$. Śmierć samobójcza jest darem, z którego każdy może skorzystać, kiedy życie stanie się dla niego nie do zniesienia. To coś absolutnie prywatnego, indywidualnego, o czym mamy pełne prawo decydować wedle własnego uznania. Żaden władca, żadne prawa stanowione nie mogą nam zabrać tego jedynego prawa decydowania o sobie. Prawo do samobójstwa jest prawem naturalnym i wynika z prawa do życia. Śmierć jest jednocześnie tym, co zrównuje wszystkich, dzięki niej wprowadza się poczucie równości i sprawiedliwości. „Dla stoickich szermierzy praw rozumu śmierć była ucieczką od nieuniknionego na padole ziemskim zła. Dla chętnych do takiej ucieczki drzwi są stale otwarte. Przeto nie skarga na boleści życia, lecz samobójstwo jest właściwym rozwiązaniem doczesnych dolegliwości człowieka" ${ }^{18}$. W ten oto sposób otrzymujemy etykę otwartych drzwi, gdzie śmierć jest tęsknotą, której człowiek wypatruje już od chwili narodzin. Jednocześnie śmierć nie powinna przyprawiać żywych o smutne myśli czy nastroje. Nie można przecież żałować tych co umarli, tak samo, jak nie żałuje się tych, którzy się nie urodzili. Żal związany z procesem umierania jest sprzeczny z rozumem i naturą ludzkiej egzystencji.

Samobójstwo jest więc nie tylko czymś dozwolonym, ale i w niektórych sytuacjach pożądanym, a jego aprobata sięga znacznie dalej, niż tylko do sposobu rozwiązania niechęci przeżywania prozaicznych trosk i problemów. Samobójstwo

14 Platon, Dialogi, tłum. W. Witwicki, t. 1, Kęty 2005, s. 632.

15 Por. też Platon, Fedon VI.C i XII.E.

16 Seneka, Myśli..., wyd. cyt., s. 161.

17 Seneka, Dialogi..., wyd. cyt., s. 129.

18 Tokarczyk R., dz. cyt., s. 96. 
jest wskazane i uznane za coś naturalnego w przypadku utraty zdrowia lub zdolności służenia społeczeństwu. Tym samym otrzymujemy tutaj jedno z pierwszych stanowisk, które propaguje samobójstwa eutanatyczne dokonywane zarówno przez samego zainteresowanego, jak i wspomagane, czyli na jego wyraźną prośbę z pomocą innych osób. Zarówno poglądy Seneki, jak i cała doktryna stoicka opiera się na umiejętności odważnego i godnego umierania w oparciu o siłę rozumu. Racjonalizm i trzeźwa ocena rzeczywistości z wyłączeniem emocji ma pozwolić ocenić moment, w którym nie ma już sensu utrzymywać życia za wszelką cenę. Życia, z którego już nic nie wynika i które nikomu nie jest potrzebne. W ten oto sposób śmierć staje się sposobem na zakończenie indywidualnych przykrości, jakie niesie życie, ale też jest uwolnieniem innych od przykrego obowiązku sprawowania opieki nad osobami pozbawionymi samodzielności. W obliczu wyjątkowej udręki, jaką jest życie, wręcz zaleca się odejście z tego świata. Jeśli ktoś jest schorowany, niedołężny lub źle się czuje oraz kiedy jest w nim to przeczucie o dokonaniu się jego żywota, nie powinien kurczowo trzymać się życia. I długość lat, jakie spędziliśmy na tym świecie, nie ma znaczenia. Gotowość na śmierć to nie kwestia tego czy ktoś wiekiem jest starcem czy młodzieńcem, ale wewnętrznej gotowości na to, aby odejść.

Nie oznacza to jednak, że spotykać będziemy u Seneki aprobatę wszelkiej formy samobójstwa czy samobójstwa wspomaganego. Samobójstwo jest formą uwolnienia się od udręki życia, ale nie może być decyzją podejmowaną pochopnie i pod wpływem emocji. "Nawet wtedy, kiedy rozum doradza nam skończyć ze sobą, ani zbyt pochopnie, ani zbyt pospiesznie nie można ulegać temu popędowi. Dzielny i mądry człowiek nie powinien uciekać z życia, ale odchodzić. Lecz przede wszystkim należy unikać tego uczucia, które ogarnia wielu: żądzy śmierci. Istnieje bowiem, mój Lucyliuszu, jakiś nieszczęsny pociąg duszy do śmierci, podobnie jak i do innych rzeczy, często opanowujący ludzi szlachetnych i o wielkich zdolnościach, a często także tchórzów i gnuśnych: tamci gardzą życiem, ci nie wytrzymują jego ciężaru. Niektórych też nachodzi przesyt robienia i oglądania wciąż tego samego, i nie tyle nienawiść do życia, ile odraza" ${ }^{19}$. Jak zatem widać powodów do samobójstwa jest wiele, jednak żaden z nich nie jest potępiany, gdyż sam czyn nie jest uznawany przez stoików za coś zdrożnego, potępiany jest stan, w jakim się go dopuszcza, czyli podejmowanie samobójstwa na skutek emocji. Bardziej też nieetycznym i nieludzkim jest uporczywe trzymanie kogoś przy życiu, niż pozwolenie mu odejść.

19 Seneka, Myśli.., wyd. cyt., s. 161. 


\section{Marek Aureliusz jako kontynuator poglądów Seneki}

W krąg zagadnień filozoficznych Aureliusza wprowadza nas refleksja nad mistycznym cyklem życia i śmierci. Spotykamy tutaj kontynuację stoickiej koncepcji nicości, do której zmierza człowiek, jak i poglądu na śmierć jako element natury, przed którym nie ma potrzeby się bronić. Sama śmierć tłumaczona jest jako „rozpadnięcie się w pył, jeżeli przyjmujesz atomy. A gdy przyjmujesz jedność, to jest to nicość lub przemiana" ${ }^{20}$. Śmierć, jest więc rozproszeniem, którego celem jest wieczna zmienność. Przechodzenie z jednego stanu w drugi. Śmierci nie należy się bać, bo „kto boi się śmierci, boi się albo braku odczuwania, albo zmiany odczuwania. [...] a jeżeli inaczej będzie odczuwał, to będzie innym stworzeniem, ale żyć nie przestanie" ${ }^{21}$. Jeśli człowiek nic nie będzie odczuwać, to pozbawiony smutku i radości po prostu przestanie istnieć. Ulegnie rozproszeniu w nicość. Jest to nieco zmodyfikowany pogląd Seneki, u którego apatia była podstawą do wejścia na droge cnoty. U Aureliusza jest ona sygnałem ostrzegawczym przed tym, że popadamy w nicość. Lęk przed śmiercią u Seneki bierze się z lęku przed niespełnieniem lub niewłaściwym przeżyciem życia. Jest emocją, która zaburza poznanie rozumowe. Aureliusz widzi w lęku przeistoczenie, a z doświadczenia śmierci należy odczuwać radość tak samo, jak z trosk, bo świadczą one o zdolności do oceny i odczuwania. Radości i smutki są nieodłącznym elementem życia, walka z nimi to jak walka z tym, co jest naturalne. Nie sposób zatem przeżyć życie wyselekcjonowawszy troski czy radości tak samo, jak nie sposób przeżyć życie bez śmierci. Z tego też powodu nie można gardzić śmiercią, gdyż jest ona elementem natury, który otrzymał każdy z nas: „Śmiercią nie gardź - owszem, niech ci miła będzie, bo i ona jest jednym z objawów woli natury. Śmierć jest czymś takim jak to, że stałeś się młodzieńcem i postarzałeś się, że dorosłeś i dojrzałeś, otrzymałeś zęby, brodę, włosy siwe, jak płodzenie, brzemienność i rodzenie i inne objawy działalności natury, które przynoszą z sobą okresy życia twego. Jest więc rzeczą człowieka myślącego nie zachowywać się wobec śmierci ani obojętnie, ani odpychająco, ani lekceważąco, owszem, czekać na nią spokojnie, jako na jeden z objawów działania natury. A z tym uczuciem, z jakim teraz czekasz na wyjście potomka z łona swej żony, oczekuj pory, w której dusza twa wyjdzie z tej oto obłsonki" 22 . Podobnie jak u Seneki zauważamy tutaj stoicką gotowość na śmierć i traktowanie jej jako tego, czego nie powinno się unikać, kiedy nadchodzi jej czas. Śmierć to wielostopniowy cykl, w którym uczestniczymy od dawna i nie ma potrzeby się

20 Aureliusz M., Rozmyślania, tłum. M. Reiter, Kęty 2008, s. 60.

21 Tamże, s. 75.

22 Tamże, s. 77. 
jej bać tak, jak nie boimy się tego, co oczywiste i naturalne. Śmierć sama nas znajdzie, tak samo, jak wielokrotnie znajdowała nas wcześniej. Jedyne, co każdorazowo zabieramy z sobą dalej, to świadomość. Należy więc ćwiczyć świadomość, rozum i pamięć, gdyż nie to, co mamy, ani kim jesteśmy, kształtuje nasze dusze i przechodzi w kolejne stany.

Nie ma więc najmniejszego sensu zamartwiać się o to, co będzie później. Żyjemy tutaj i teraz. Jest to dany nam czas, aby pracować nad sobą, bo tylko to, kim jesteśmy tutaj i czego dla swojego rozwoju dokonamy teraz, będzie służyć nam tam. A tam staniemy, kiedy rola, jaką mamy do odegrania w przedstawieniu, zostanie wyczerpana. „Tak, jak aktora usuwa ze sceny pretor, który go przyją”” 23 tak i my zostaniemy usunięci. A jeśli ktoś podnosi bunt, że oto odegrał w życiu tylko trzy akty, a nie pięć, to i to dobrze. Widocznie w jego „życiu trzy akty tworzą całość. Bo kiedy się ma skończyć, wyznacza ów, kto przedtem zespół ułożył, a teraz rozpuszcza. Ty zaś ani w jednym, ani w drugim udziału nie brałeś. Odejdź więc łagodnie. Łagodny bowiem jest i ten, kto cię zwalnia" ${ }^{24}$. A gdy zwolnieni zostaniemy, staniemy po drugiej stronie nie nadzy nawet, ale wyposażeni jedynie w rozum, który nam służy tak samo tutaj, jak i będzie służyć tam. Nie jest więc ważnym, co się posiada, jakie dobra gromadzi i jakie funkcje piastuje. Ważne jest to, jak wyćwiczymy w bojach życia nasz rozum, gdyż będzie to jedyny oręż i jedyny dobytek, jaki z sobą zabierzemy w dalszą podróż.

Dalsza podróż to oczywiście powrót do jedności z wszechświatem, kiedy to człowiek zostanie rozproszony na poszczególne elementy: „Składam się z pierwiastka przyczyny i tworzywa. Ani jedno, ani drugie nie zmarnieje w nic, tak jak nie powstało z niczego. Każda więc moja cząstka przez przemianę przejdzie w jakąś cząstkę wszechświata. A owa znowu w inną jakąś cząstkę wszechświata się zmieni, i tak w nieskończoność. Taką to przemianą i ja powstałem, i moi rodzice, i tak wstecz w nieskończoność" ${ }^{25}$. Mądrość polega więc na gotowości przyjęcia śmierci i na opanowaniu przed nią lęku. Tymczasem doświadczenie uczy nas, że w przypadku niebezpieczeństwa zagrożenia życia ogarnia nas strach, wpadamy w popłoch i rozpaczamy nad utratą życia. „Powodem jest to, że brak nam wszelkich dóbr wewnętrznych, i dlatego cierpimy z powodu utraty życia. Nie pozostała w nas żadna jego cząstka: minęło ono i bezpowrotnie odeszło. Nikt nie troszczy się o to, jak żyć dobrze, lecz jak żyć długo, jakkolwiek wszyscy mogą się zdobyć na dobre życie, a nikt nie może sprawić, że będzie żył długo" 26 .

23 Tamże, s. 106.

24 Tamże.

25 Tamże, s. 43-44.

26 Seneka, Myśli, wyd. cyt., s. 160. 
Niezależność od śmierci, brak wpływu na proces umierania zbliża nas do niej, pozwala z nią się oswajać i obcować, niczym z niewidzialnym członkiem rodziny. Im wygodniejsze jest nasze życie, im więcej w nim planów i zamierzeń, tym trudniej jest się nam z nim rozstać. Wówczas ,albo tu żyjesz i już się do życia przyzwyczaiłeś, albo sam się wynosisz na tamten świat i tego chciałeś, albo umierasz i służbę swą odbyłeś" 27 . Możliwości są zatem trojakie, ale czy to oznacza, że Aureliusz, podobnie zresztą jak stoicy, jest zwolennikiem samobójstwa, jako sposobu na rozwiązanie problemu życia? Samobójstwo jest doskonałym rozwiązaniem, jeśli umysł zawodzi, siły nas opuszczają, zaś organizm nadal trzyma się życia. Wówczas człowiek, póki jeszcze myślenie go nie opuściło, powinien powziąć decyzję, czy warto usilnie pozostawać na deskach teatru, skoro rola już odegrana. „Gdy się bowiem zacznie dziecinnieć, pozostanie wprawdzie zdolność oddychania i karmienia się, i tworzenia wyobrażeń, i pożądanie itd., ale gaśnie zdolność władania sobą samym i umiejętnego zdawania sobie sprawy z obowiązków, i porządkowania zjawisk, i zdolność osądzania, czy już należy stąd wynieść się samemu, i to wszystko, co w wysokim stopniu wymaga umysłu wyćwiczonego. Należy się więc spieszyć, i to nie tylko dlatego, że każdej chwili bliżsi stajemy się śmierci, ale i dlatego, że ustaje zdolność wnikania w zdarzenia i ich zrozumienia" ${ }^{28}$. Zatem kiedy nie możemy samodzielnie funkcjonować, kiedy nie możemy wypełniać naszych obowiązków lub kiedy po prostu rola, jaką mieliśmy do spełnia, została wypełniona, powinniśmy odejść z tego świata tak, jak marynarz schodzi z okrętu, kiedy po wyznaczonej podróży dobija do ostatniego portu. Samobójstwo jednak powinno być popełniane, podobnie jak u Seneki, zgodnie z rozumem, bez emocji i w przemyślany sposób. „Jak byś po śmierci chciał, by ci życie było upłynęło, tak żyć tu na ziemi możesz. A gdyby ci na to nie pozwalano, to ustąp z życia. Tak jednak, jakbyś nie odczuwał żadnej przykrości. Dym tu - więc odchodzę. Czemuż to uważasz za rzecz wielką? Ale jak długo nic takiego mnie stąd nie wypędza, dobrowolnie pozostaję i nikt mi nie wzbroni czynić tego, co chcę. A chcę tego, co jest zgodne z naturą stworzenia obdarzonego rozumem, do współżycia przeznaczonego" 29.

Stoickie podejście do śmierci oraz stosunek do samobójstwa jest kontrowersyjny głównie dlatego, że jest to stanowisko radykalne i stanowi skrajną wersję poglądów poprzedników, którzy nawet jeśli akceptowali akt samobójczy, to nie był on rozpatrywany jako indywidualny sposób na zakończenie złego życia, ale jak np. w przypadku Arystotelesa, w kontekście społecznym.

\footnotetext{
27 Aureliusz M., wyd. cyt., s. 88.

28 Tamże, s. 24.

29 Tamże, s. 46.
} 
Człowiek dla Arystotelesa jest istotą społeczną, stworzeniem politycznym i co za tym idzie, jego odejście powinno być rozpatrywane na tle korzyści lub straty, jaka się z tym wiąże dla większości. Samobójstwo, to ucieczka od obowiązków, jakie każdy obywatel ma względem państwa. Jest ono tolerowane, kiedy staje się ostatecznością, ale kiedy ma służyć wyłącznie za ucieczkę przed troskami, wówczas jest zwykłym tchórzostwem. U Seneki jest ono wyrazem wolności i prawa do samodecydowania o swoim losie. „Rozmyślaj o śmierci. Ten, kto tak mówi, każe rozmyślać o wolności. Kto nauczył się śmierci, oduczył się niewoli. Znajduje się on ponad wszelką władzą, a w każdym razie całkowicie poza nią. Czymże dla niego więzienie, kajdany, kraty? Ma przecież otwarte drzwi. Jest tylko jeden łańcuch, który nas skuwa: miłość życia, której wprawdzie nie należy całkiem od siebie odpychać, lecz jednak trzeba ją zmniejszać, aby wtedy, kiedy zażąda konieczność, nic nas nie krępowało ani nie przeszkadzało nam nic, przez co bylibyśmy mniej gotowi zrobić natychmiast, co i tak kiedyś będziemy musieli zrobić" 30 . Pamiętać jednak należy, że wprawdzie samobójstwo jest doniosłym, ale nie jedynym rodzajem śmierci. Z pewnością jednak nie możemy rozpatrywać go wyłącznie w kategorii ucieczki czy rezygnacji. Nie taka była intencja stoików. Dla nich samobójstwo to akt wymagający dojrzałości i odwagi, aby wiedzieć, kiedy z godnością należy się wycofać. „Wielka to rzecz, Lucyliuszu, i wymaga długiej nauki: odejść spokojnie, kiedy nadchodzi owa nieunikniona chwila. W innych rodzajach śmierci tkwi choćby szczypta nadziei: choroba ustępuje, pożar gaśnie, cało uchodzą przywaleni, jak się zdawało, gruzami; morze z tą samą siłą, z jaką pochłania rozbitków, wyrzuca ich nietkniętych; żołnierz cofa miecz znad samego karku ofiary: lecz ten, kogo starość wiedzie ku śmierci, nie ma się czego spodziewać. Tej jednej śmierci nic nie przeszkodzi. Żaden inny koniec nie jest mniej bolesny, ale żaden bardziej przewlekły" 31. Toteż tych, którzy uparcie chcieli żyć odwlekając czas śmierci, nie warto nawet wspominać. Życie jest nie po to, aby korzystać z dóbr, ale by szukać prawdy, zaś człowiek „taką przedstawia wartość, jaką mają przedmioty jego starań” 32. Toteż zmierzając ku śmierci należy tak żyć, aby „niczego nie żałować, skromnie wszystko przyjmować i tracić” 33 , bo „skoro niepodobna zapanować nad światem, trzeba zapanować nad sobą" 34.

Samobójstwo, jako sposób na rozwiązanie problemów egzystencjalnych, znajduje u każdego inne wytłumaczenie. Na poglądy Seneki wpływ miała sytuacja polityczna, w której cokolwiek jest lepsze, niż pozostanie tutaj pod władzą Ne-

\footnotetext{
30 Seneka, Myśli.., wyd. cyt., s. 162.

31 Tamże, 163.

32 Aureliusz M., Rozmyślania, wyd. cyt., s. 72.

33 Tamże, s. 89.

34 Tatarkiewicz W., Historia..., wyd. cyt., s. 132.
} 
rona. Marek Aureliusz swoje widzenie śmierci i cierpienia budował przez pryzmat śmierci Faustyny. W obu przypadkach śmierć jest furtką do wolności w sytuacji całkowitego zniewolenia i niezadowolenia z życia.

\section{Dzisiejszy problem samobójstw}

Współcześnie samobójstwo na wzór jego stoickiego rozmienia może posłużyć jako argument usprawiedliwiający śmierć wspomaganą, gdzie świadomość zainteresowanego domaga się, by odejść z tego świata, ale fizyczny stan zdrowia uniemożliwia, aby dokonać tego osobiście. Z całym przekonaniem możemy więc powiedzieć, że filozofia stoicka dała podwaliny pod to, co dziś nazywamy eutanazją i prawem do godnej śmierci. „Usiłowała dowieść, że samobójstwo nie tylko da się wyjątkowo uzgodnić z wymogami etyki, ale stanowi ich prostą i ostateczną konsekwencję. Do tego wszakże konieczny jest odpowiednio dobrany punkt wyjścia. U stoików rolę tę pełni teza, że źródło i siła twórcza moralnego postępowania człowieka polega na działaniu zgodnym z jego naturą i powszechnym porządkiem świata" ${ }^{35}$. Dzisiejsze koncepcje eutanatyczne dozwalają śmierć, jednak z ograniczeniem miejsca, gdyż nie wszystkie kraje w swoich regulacjach prawnych godzą się na to rozwiązanie, oraz wyłącznie w skrajnych przypadkach. Jedynym ograniczeniem dla Stoików było podejmowanie takiej decyzji w emocjach oraz fakt, że przywilej ten przysługiwał wyłącznie mędrcom, czyli wybranej grupie społecznej.

Dzisiaj zaledwie kilka krajów otworzyło prawną możliwość do godnej śmierci, której powodem do wykonania jest własne wyrażenie woli. Chociaż Stoicy dali nam cały katalog przypadków, w jakich powinniśmy pogodzić się z kresem swojego życia, nadal stosowane są uporczywe terapie utrzymywania przy życiu, chociaż wiadomo, że ma żadnych rokowań na poprawę.

Prawo do śmierci wydaje się być tak oczywistym, jak prawo do swobodnego dysponowania własnym majątkiem. Nic jednak bardziej mylnego. Prawo do śmierci ogranicza się wyłączenie do warunków, w jakich powinien umierać człowiek. Nie ma ono nic wspólnego z możliwością wyboru, sposobu czy czasu, a jedynie z warunkami w jakich człowiek powinien odchodzić. Mimo usilnych próśb chorych o skrócenie ich cierpień i pomoc w odejściu, ignoruje się te potrzeby i na siłę utrzymuje przy życiu. Zwolennicy eutanazji w odmowie pomocy przy samobójstwie powołują się tutaj na szereg argumentów mających przemawiać za dozwoleniem eutanazji. W debatach pojawia tak pojęcie wolnej woli, jak i celowość utrzymywania przy życiu osób, które nigdy nie odzyskają świadomości,

35 Ślipko T., Etyczny problem samobójstwa, Kraków 2008, s. 11. 
aż po względy ekonomiczne. Dla przeciwników podstawowym argumentem jest prawo do życia i boska wyłączność do decydowania o śmierci.

Sporadyczne przypadki powrotu do zdrowia, nadużycia itp. mogą stanowić argument przeciw eutanazji, jednak w momencie oświadczenia woli przy pełni władz umysłowych i z wyraźnej inicjatywy zainteresowanego, powinno brać się pod uwagę wyłącznie pragnienie osoby, która chce się dopuścić samobójstwa. Niestety w większości krajów pod uwagę bierze się wyłącznie martwą literę prawa, a nie prośbę chorego. Problem ten w zasadzie nie istnieje dla osób mogących samodzielnie egzystować, ale w przypadku tych, którzy nie mogą tego dokonać samodzielnie, etyka otwartych drzwi nie jest możliwa, zaś zainteresowanie ich sytuacją zaczyna się dopiero wówczas, kiedy kierują oni do sądów prośbę o wydanie zgody na eutanazję. Wówczas to jesteśmy świadkami gwałtownego zainteresowania się takimi osobami i ich losem.

Organizowanie im czasu, szukanie zajęć i tworzenie aury bycia potrzebnym jest w gruncie rzeczy środkiem doraźnym. Nie rozwiązuje to problemu bezradności wobec życia, całkowitego uzależnienia od innych lub perspektywy niedołęstwa czy pozostawania w stanie wegetatywno-pasywnym. Dlatego właśnie, nawet w dzisiejszych czasach, warto wziąć pod uwage poglądy stoików w ocenie dopuszczalności samobójstwa, chociażby jako możliwości skrócenia cierpienia. Opowiedzenie się za stosowaniem eutanazji nie oznacza przecież konieczności korzystania z tego środka, zaś realnym problemem nie jest kwestia legalizacji, ale sposób i okoliczności sięgania po tę możliwość.

Stoicy opowiadali się za samobójstwem w sytuacjach, które obecnie wydawać się nam mogą zbyt błahe, aby z tego powodu kończyć życie, jednak problem zdrowotny pozostaje aktualny do dziś i właśnie z tego powodu należy wziąć pod uwagę, czy nie byłoby właściwym, aby eutanazja i samobójstwo wspomagane były prawnie dozwolone, gdyż za literą prawa powinna w pierwszej kolejności iść wola osoby pragnącej zakończyć swoje życie. Prawo tym samym powinno mieć tutaj zupełnie inne zastosowanie i zamiast ścigać tych, którzy przeprowadzają eutanazję lub w inny sposób udzielają pomocy w samobójstwie, powinno chronić osoby podejmujące te trudną również dla siebie decyzję, aby ich wola została spełniona, zaś intencje właściwie odebrane.

\section{Seneca's views on suicide and its relevance to the contemporary debate on the acceptability of euthanasia and assisted suicide}

\section{Summary}

The main purpose of this article is to analyse the ideas presented and formulated by Seneca the Younger and Marcus Aurelius on topics related to suicide. At the same time I also try to present their importance and validity in 
various debates based on both legal and philosophical aspects to allow assisted suicide and euthanasia.

Assisted death (suicide) presents a serious issue in a legal sense, as we witness some sort of collision between our statement of will in relation to our life, and, on the other hand, attempting suicide or aiding someone to commit suicide, both of which are considered criminal offences in a large number of legal systems around the world.

In numerous debates on assisted suicide it needs to be remembered that even in liberal thoughts emphasized by Stoics there are certain limitations and restrictions.

However, this article is not only concerned with Stoics' thoughts and arguments in favour of assisted suicide in everyday life but it is also an attempt to emphasize the legal aspects of aiding someone in committing suicide. Finally, the article brings up the question of how far the law should interfere into a human will despite protecting it and turning a will into an offence.

Key words: assisted suicide, assisted death, death, euthanasia, manslaughter, liability, joint liability, abetting, stoicism

Słowa kluczowe: samobójstwo wspomagane, asystent śmierci, śmierć, eutanazja, zabójstwo, sprawstwo i współsprawstwo, stoicyzm

\section{Bibliografia}

Aureliusz M., Rozmyślania, przeł. M. Reiter, Kęty 2008.

Karłowicz D., Problem samobójstwa. Refleksje nad ocena moralna samobójstwa u starożytnych filozofów, „Znak”, 12, 1997.

Platon, Dialogi, przeł. W. Witwicki, t. 1, Kęty 2005.

Seneka, Myśli, przeł. S. Stabryła, Gdańsk 2000.

Seneka, Dialogi, przeł. S. Stabryła, Warszawa 1998.

Ślipko T., Etyczny problem samobójstwa, Petrus, Kraków 2008.

Tacyt, Dzieła, przeł. S. Hammer, Warszawa 2004.

Tatarkiewicz W., Historia filozofii, t. 1, Warszawa 1968.

Tokarczyk R., Prawa narodzin, życia i śmierci, Lublin 1995.

\section{Źródła elektroniczne:}

http://www.diritto.it/docs/32741-euthanasia-last-life-right-and-albanian-legislation? page $=1$

Michał Kamiński - doktorant na Wydziale Prawa Uniwersytetu Jagiellońskiego w Katedrze Filozofii Prawa. Absolwent IF UAM w Poznaniu oraz WSAP w Łodzi. 
